\title{
Cushing's Syndrome Associated with an Islet-cell Tumour of the Pancreas in a Boy Aged 2 Years
}

\author{
J. H. BURKINSHAW, D. O'BRIEN, and J. E. H. PENDOWER \\ From Mayday Hospital, Croydon, London
}

We present this case because, so far as we can discover, no similar one has yet been reported in a child.

\section{Case History}

This boy was born in June 1963. He presented at the out-patient clinic in September of 1965 at the age of 2 years and 3 months, on account of sudden excessive weight gain. He had been healthy and free of symptoms until 6 weeks before, when he had suddenly developed a ravenous appetite ('he will eat two of every meal I offer him'). He had become very fat and his face had become very red. His weight four weeks before his attendance had been $12.7 \mathrm{~kg}$.: now he weighed $15.9 \mathrm{~kg}$. There were no other symptoms, and he was lively and cheerful, with no polydipsia or polyuria. He had never had a fit, faint, or episode of disordered consciousness, such as might be caused by hypoglycaemia. His birthweight had been $2.7 \mathrm{~kg}$., and the perinatal period and infancy had been uneventful. The parents were both alive and well, and not of abnormal size or weight. The paternal great grandfather was short and fat. He had one brother aged 4 years alive and well, weighing at present $13.5 \mathrm{~kg}$.

Examination. He was very fat (Fig. 1), weight $15.9 \mathrm{~kg}$. (97th centile), height $88 \mathrm{~cm}$. (50th centile). $\mathrm{He}$ had a red moon face, and there was a faint brownish pigmentation of the entire skin, but no pigment inside the mouth. The genitalia were not enlarged and there was no hirsutes. Blood pressure estimations were difficult owing to the excessive amount of fat and to the child's dislike of the procedure. Two readings of $110 \mathrm{~mm} . \mathrm{Hg}$ were recorded by the flush and palpation methods using a $10 \mathrm{~cm}$. cuff. A firm, non-tender rounded mass about the size of an orange could be felt in the left hypochondrium. It did not move on respiration and did not extend backward into the loin. No other abnormalities were found. A provisional diagnosis was made of a rapidly growing, probably suprarenal tumour, and the child was admitted at once into the ward.

Investigations. Table I shows the results of a series of chemical and steroid metabolic studies which were carried out by Dr. A. Tickner at various times during and after the patient's stay in hospital. Figures appearing to the left of the double vertical line were obtained before

Received December 15, 1966. the operation, and those to the right were obtained after it. Attention is directed to the grossly raised plasma cortisol and urinary oxogenic steroid excretion observed two days after he had presented. Other pre-operative data were: $\mathrm{Hb} 11 \cdot 7 \mathrm{~g} . / 100 \mathrm{ml}$. Total WBC $9000 /$ c.mm., neutrophils $66 \%$, lymphocytes $31 \%$, monocytes $3 \%$. Intramuscular pyelogram (Dr. L. J. Sandell): the lower pole of the left kidney was displaced slightly medially. The large soft tissue mass appeared to lie below and lateral and possibly anterior to the kidney, and was displacing the splenic flexure downwards. No calyceal abnormality and no suprarenal tumour. Skull $x$-ray film: no abnormality of the sella turcica.

Operation. (J.E.H.P.). An oblique abdominal incision was converted into thoraco-abdominal through the 9th left interspace. A large retroperitoneal tumour was

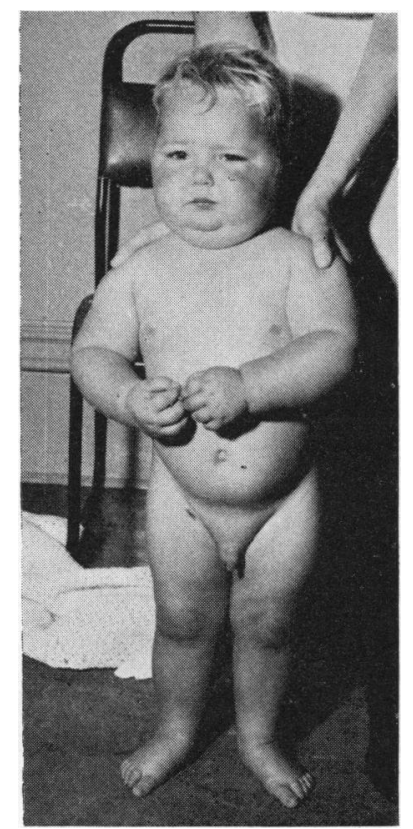

FIG. 1.-The patient on admission in September 1965. 
TABLE I

Chemical and Adrenocortical Studies

\begin{tabular}{|c|c|c|c|c|c|c|c|c|c|c|}
\hline \multirow{2}{*}{\multicolumn{4}{|c|}{ Parameter }} & \multirow{2}{*}{$\begin{array}{c}\text { Normal } \\
\text { Value }\end{array}$} & \multicolumn{6}{|c|}{ Date } \\
\hline & & & & & 30.9 .65 & 8.10 .65 & 10.10 .65 & 19.10 .65 & 2.1 .66 & 7.7 .66 \\
\hline $\begin{array}{l}\text { Blood urea (mg./100 ml.) } \\
\text { Blood glucose }(\mathrm{mg} / / 100 \mathrm{ml} .) \\
\text { Plasma sodium (mEq/1.) } \\
\text { Serum potassium (mEq/l.) } \\
\text { Plasma chloride (mEq/1.) } \\
\text { Plasma bicarbonate }(\mathrm{mEq} / 1 .) \\
\text { Urinary } 17 \text {-oxosteroid excret } \\
\text { Urinary 17-oxogenic steroid } \\
\text { Plasma cortisol }(\mu \mathrm{g} . / 100 \mathrm{ml} .)\end{array}$ & $\begin{array}{ll}\cdots & \cdots \\
\ldots & \cdots \\
\cdots & \cdots \\
\cdots & \cdots \\
\text { tion (mg./day) } \\
\text { excretion (mg. } \\
\quad\end{array}$ & $\begin{array}{l}\cdots \\
\cdots \\
\cdots \\
\cdots \\
\cdots \\
\text { iday) }\end{array}$ & \begin{tabular}{l|}
$\cdots$ \\
$\cdots$ \\
$\cdots$ \\
$\cdots$ \\
$\cdots$ \\
$\cdots$ \\
$\cdots$
\end{tabular} & $\begin{array}{c}20-40 \\
60-120 \\
137-147 \\
3 \cdot 5-5 \cdot 5 \\
96-105 \\
23-29 \\
0-4 \\
0-4 \\
6-26\end{array}$ & $\begin{array}{c}66 \cdot 0 \\
145 \cdot 0 \\
4 \cdot 5 \\
119 \cdot 0 \\
26 \cdot 1 \\
3 \cdot 75 \\
14 \cdot 1 \\
72 \cdot 0\end{array}$ & $\begin{array}{c}139 \cdot 0 \\
4 \cdot 85 \\
110 \cdot 0 \\
26 \cdot 6\end{array}$ & $\begin{array}{c}24 \cdot 0 \\
113 \cdot 0 \\
134 \cdot 5 \\
4 \cdot 65 \\
106 \cdot 0 \\
27 \cdot 9\end{array}$ & $6 \cdot 0$ & $\begin{array}{c}137 \cdot 5 \\
5 \cdot 1 \\
100 \cdot 0 \\
27 \cdot 9 \\
0 \cdot 65 \\
3 \cdot 3 \\
55 \cdot 5\end{array}$ & $12 \cdot 6$ \\
\hline
\end{tabular}

found in the left hypochondrium. Liver, spleen, kidneys, and paraortic lymph glands were normal. The tumour was mobilized and found to be in the tail of the pancreas. Distal hemipancreatectomy was performed, the spleen also being removed. The left adrenal gland was seen to be the size of a forefinger nail, and thin. It was thought to be normal in size. The right adrenal was also felt to be normal. The wound was closed according to routine practice, with a drain in the left subphrenic space and an underwater chest drain. The child made a good recovery from the operation. The only complication was a serous discharge from the wound which dried up after a few days. The patient was discharged

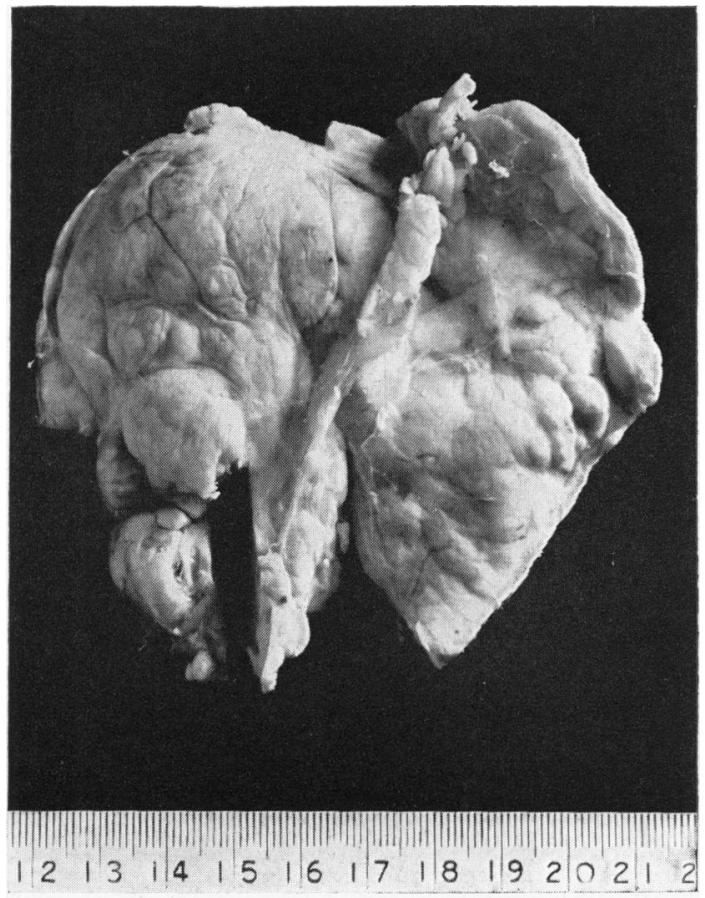

Fig. 2.-The specimen removed at operation. home on November 2, 1965. His weight on the day of discharge was $13 \cdot 6 \mathrm{~kg}$.

Steroid cover. Steroid cover was started 12 hours before the operation. The patient was given hydrocortisone acetate by intramuscular injection for four days, during which he received a total of $650 \mathrm{mg}$. On the fifth day after operation he began to take prednisolone by mouth in doses of $5 \mathrm{mg}$. twice daily for 12 days; thereafter the dose was reduced progressively and by November 5 the steroids were discontinued altogether.

Tumour. (D. O'B.). The specimen removed at operation weighed $21 \mathrm{~g}$. It consisted of a slightly lobulated, roughly spherical mass (Fig. 2), covered by a thin translucent capsule. The soft, rather brain-like cut surface was varied in some places by fine stippling with tiny blood spaces. A piece of pancreas about $1.8 \times 1$ $\mathrm{cm}$. with normal glandular appearance was attached to the tumour. Sections showed a tumour composed of small polygonal or spherical cells which in places closely resembled the cells of the islets of Langerhans in the attached normal part of the pancreas (Fig. 3). There was moderate variation of cell type through the tumour. In some places there were larger cells with large irregular nuclei and moderate numbers of mitoses. These, and the presence of groups of tumour cells in blood spaces and lymphatics, suggested malignancy (Fig. 4 and 5). A few areas of cystic degeneration were present. The vascular areas were composed of sinusoid blood spaces. Hyperplasia of duct epithelium ('nesidioblastosis')sometimes found accompanying islet cell tumours-was not seen. In haematoxylin and eosin stained sections at least two cell types were shown; one type with pale clear cytoplasm and the other with a distinctly granular eosinophil cytoplasm somewhat similar to the granular cytoplasm of some carcinoid tumours (Fig. 6). Using performic acid, alcian blue, PAS, and orange $G$, the cytoplasmic granules in some cells stained in a manner similar to that of the S-type pituitary basophil cell.

Follow-up. The patient has been followed up in the out-patient department. He has remained well and active. His appetite had returned to normal within a month of his discharge from the ward.

In January 1966 he was readmitted for assessment. At that time his weight was $12 \cdot 2 \mathrm{~kg}$. and his height $88 \mathrm{~cm}$. 


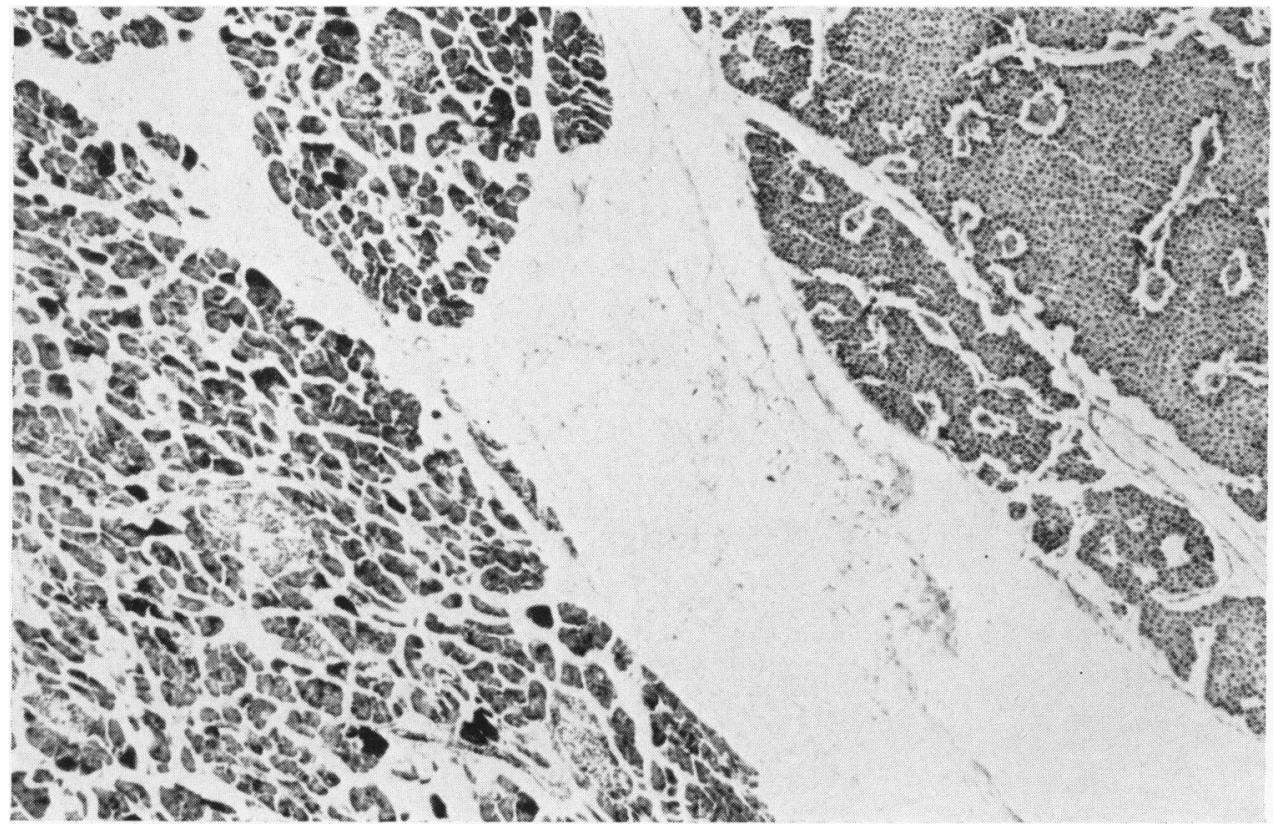

Fig. 3.-Normal pancreas (lt.) and tumour tissue (rt.). ( $\times 30$.

His systolic blood pressure was $125 \mathrm{~mm}$. Hg. The results of a sugar tolerance test together with corresponding plasma insulin levels (kindly estimated by Dr. E. Samols, Royal Free Hospital) are shown in Table I.
We asked Dr. Samols to comment on the insulin levels and he writes as follows: 'The fasting plasma insulin is normal. The insulin response to glucose is a little unusual in that the level falls at the one hour sample.

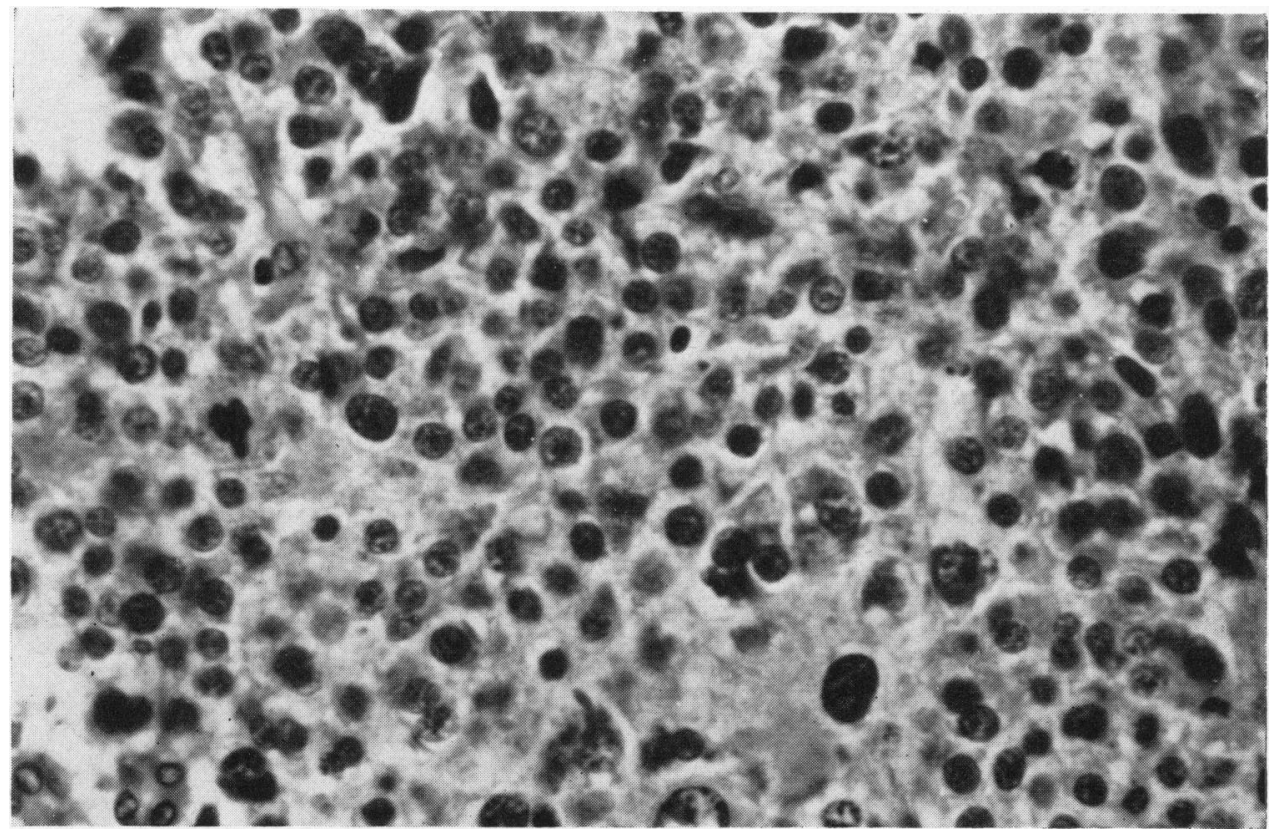

FIG. 4.-Variation in nuclear size in tumour and a tripolar mitosis. $(\times 320$. 


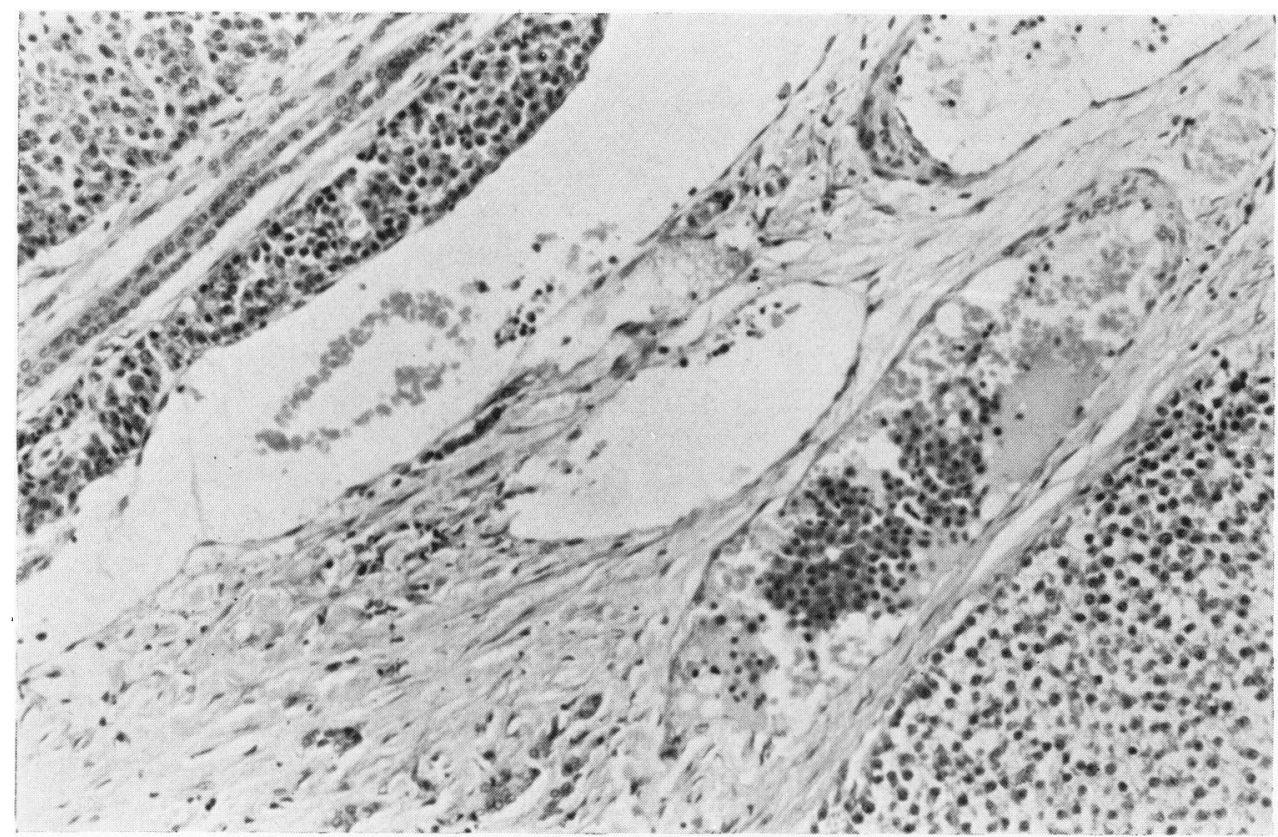

FIG. 5.-Showing tumour cells within a blood space. ( $\times$ 80.)

Apart from the unusual pattern of the insulin response, I would have to regard the absolute insulin levels at $\frac{1}{2}$ hour, $1 \frac{1}{2}$ hours, and 2 hours as within the normal range.'
The values for blood electrolytes, plasma cortisol, and the urinary excretion of steroids are shown in Table I. The abnormally high value $(55 \cdot 5)$ of plasma cortisol

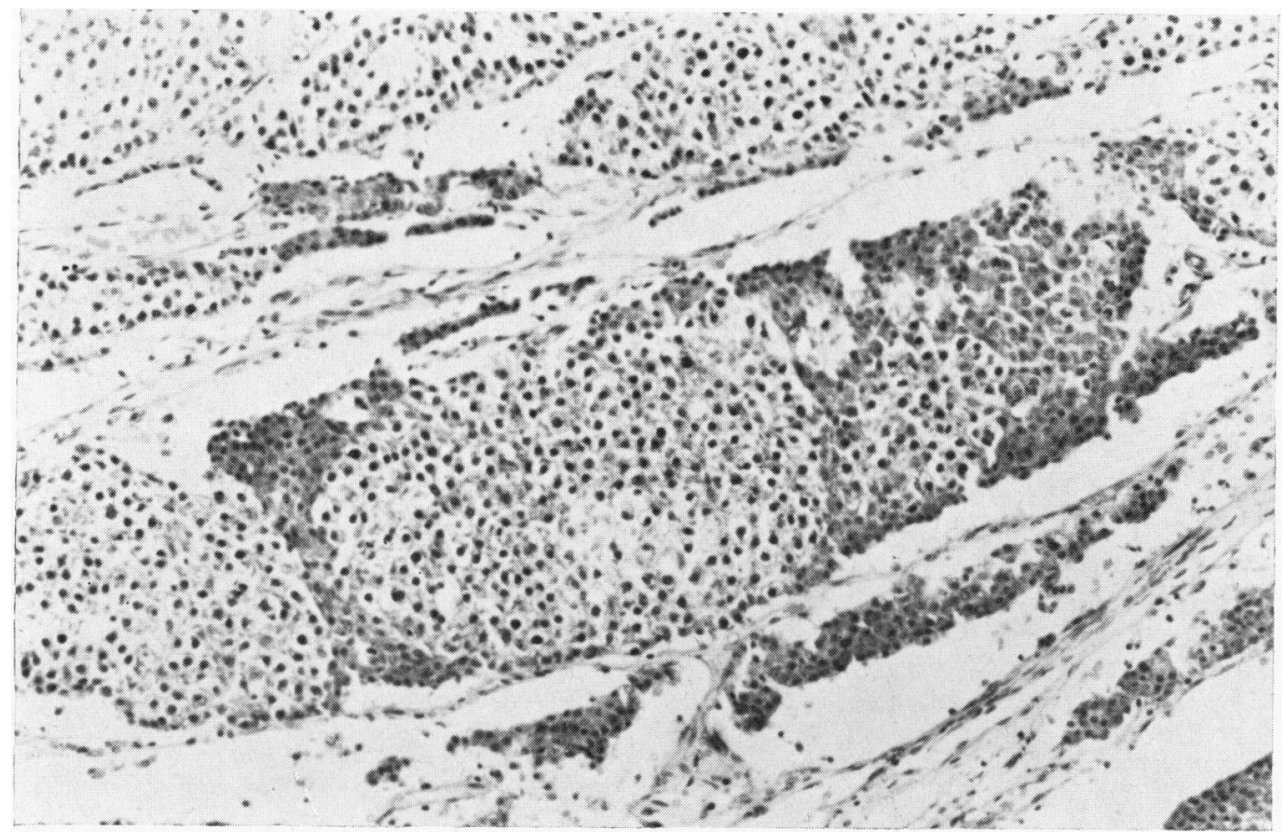

FIG. 6.-Showing tumour cells with granular and with non-granular cytoplasm. $(\times 80$. 
TABLE II

Sugar Tolerance (20 g. Glucose) and Plasma Insulin Levels

\begin{tabular}{|c|c|c|c|c|}
\hline Time & & & $\begin{array}{l}\text { Blood Glucose } \\
\text { (mg./100 ml.) }\end{array}$ & $\begin{array}{l}\text { Plasma Insulin } \\
\text { (units/ml.) }\end{array}$ \\
\hline $\begin{array}{l}\text { Fasting } \ldots \\
\frac{1}{2} \mathrm{hr} \text {. after glucose } \\
1 \mathrm{hr} \text {. after glucose } \\
1 \frac{1}{2} \mathrm{hr} \text {. after glucose } \\
2 \mathrm{hr} \text {. after glucose }\end{array}$ & $\begin{array}{l}\cdots \\
\cdots \\
\cdots \\
\cdots\end{array}$ & $\begin{array}{l}\ldots \\
\cdots \\
\cdots \\
\cdots\end{array}$ & $\begin{array}{r}59 \\
98 \\
98 \\
103 \\
94\end{array}$ & $\begin{array}{l}17 \\
63 \\
18 \\
28 \\
40\end{array}$ \\
\hline
\end{tabular}

contrasted with the substantially normal values for other parameters, and gave rise to some anxiety. The patient was seen again in July 1966 when the plasma cortisol had fallen to $12 \cdot 6 \mu \mathrm{g} . / 100 \mathrm{ml}$. He has continued healthy, and when last seen in October 1966 his appearance was as shown in Figure 7 . His weight was $14 \mathrm{~kg}$. (25th centile) and his height $92 \mathrm{~cm}$. (25th centile). A letter from his mother received in November 1966 states that he is still well.

\section{Comment}

The modern concept of Cushing's syndrome embraces a wide variety of clinical features, including not only those cited in Cushing's original description (Cushing, 1932), but also many additional features that have been added to the syndrome

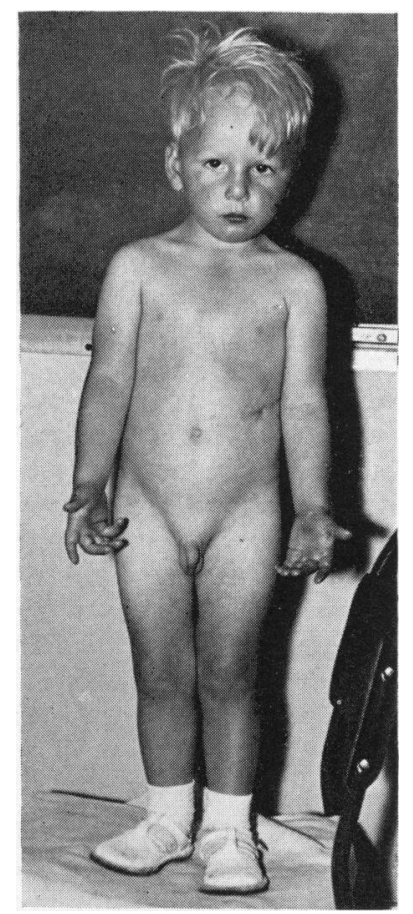

FIG. 7.-The patient in July 1966. by later observers. In any given case many of these clinical features may be absent so that today it is necessary to clinch the diagnosis of Cushing's syndrome by finding evidence of increased adrenocortical activity derived from tests of corticosteroid metabolism. Ross, Marshall-Jones, and Friedman (1966) have listed a number of such tests and have discussed the value and limitations of each in the diagnosis of Cushing's syndrome due to primary disease of the adrenal. In their experience the most useful test is the measurement of the amount of free cortisol in the urine, and the next most reliable is the dexamethasone suppression test, adrenal overactivity being strongly suggested by failure of this substance to suppress the urinary excretion of 17-ketogenic steroids below $3 \mathrm{mg}$./day. They consider the estimation of the plasma cortisol to be of limited value, and point out the normal diurnal rhythm of this substance in the blood, the lowest level being at midnight and the highest at 9 a.m.

Friedman, Marshall-Jones, and Ross (1966), reporting the results of adrenocortical function tests in their 9 cases of Cushing's syndrome associated with non-adrenal tumours, found an increase in the urinary excretion of 17-ketogenic steroids in all their cases. The plasma cortisol level was persistently raised in all the 8 cases in which it was measured. The diurnal rhythm was lost in all 5 of those in which it was studied.

In our patient the estimations of the plasma cortisol level were all done on blood that had been taken between 9 and 10 a.m. The level of $72 \mu \mathrm{g} . / 100 \mathrm{ml}$. was grossly abnormal, as was the urinary 17-oxosteroid excretion of $14 \cdot 1 \mu \mathrm{g}$./day. These findings, together with the strikingly Cushingoid appearance of the child when first seen, justify the diagnosis of Cushing's syndrome. The remarkably low level of plasma cortisol $(6.0 \mu \mathrm{g} . / 100 \mathrm{ml}$.) observed 11 days after the operation was doubtless caused by the heavy dosage of cortisone and prednisolone which the patient had been receiving since the operation. No explanation is offered for the very high level found in January 1966. It is interesting that the electrolytes remained substantially within normal limits throughout the period of observation. Bagshawe (1960), O'Riordan, Blandshard, Moxham, and Nabarro (1966), and Friedman et al. (1966), discussing their cases of non-adrenal neoplasms associated with Cushing's syndrome, stressed the frequency with which hypokalaemic alkalosis with severe muscle weakness was found. It is possible that in our patient there had not been time for this to occur. Another possibility is that our patient, being a child, would normally be growing and thus anabolizing potassium. This 
mechanism might overshadow the potassium-losing effect of adrenal overactivity. A further point of interest in this case is the absence of symptoms of hypoglycaemia. It is true we did not study the sugar metabolism of our patient, but the isolated pre-operative value of $66 \mathrm{mg}$. $/ 100 \mathrm{ml}$. glucose in the blood, together with the total absence of hypoglycaemic symptoms, explains our lack of interest in his pancreatic function, though with hindsight we might perhaps have considered the possibility of a pancreatic cause for the obesity (Frantz, 1959).

One last point of interest is the fact that our patient is alive and well one year after the operation. Friedman et al. (1966) give their opinion that the finding of adrenocortical hyperactivity in patients with neoplasms carries an extremely poor prognosis for life. The presence of tumour cells in the blood spaces of our patient's tumour, and the finding of mitotic figures in the cells, gave rise to gloomy forebodings, and it is certainly too soon to be optimistic. Nevertheless, a year's period of healthy survival is encouraging.

\section{Discussion}

Cushing's syndrome in its modern connotation associated with non-adrenal tumours is well documented. Before Cushing's paper had appeared Brown (1928) described a woman, aged 45, who died after an illness lasting 5 months, with features of what was later to be called Cushing's syndrome. At necropsy an oat-cell carcinoma of the lung was found, together with adrenal hyperplasia. Since then there have been numerous reports of individual cases, and Allott and Skelton (1960) collected 38 from the literature, adding 2 of their own. More recently, O'Riordan et al. (1966) reported their experience of 5 personal cases, and summarized the situation of the primary tumour in 118. Friedman et al. (1966) reported on 9 personal cases. Both teams of workers give a comprehensive bibliography of the subject. By far the commonest primary tumour is an oat-cell carcinoma of the lung, but tumours in many other sites have been reported, including islet-cell tumour of the pancreas.

Islet-cell tumour of pancreas associated with Cushing's syndrome. The first case of this association was described by Castillo, del Trucco, and Manzuoli (1950). Eight further cases have been reported by Rosenberg (1956), Armando (1957), Bourgeois, Rogé, Clément, Martin and, Descamps (1959), Balls, Nicholson, Goodman, and Touchstone (1959), Farrant and Insley (1960), Meador, Liddle, Island, Nicholson, Lucas, Nuckton, and Luetscher (1962), Jarett, Lacey, and Kipnis
(1964), and Marks, Samols, and Bolton (1965). The literature contains no account of this syndrome in a child.

The mechanism whereby non-adrenal tumours can produce adrenal overactivity has been illuminated by Holub and Katz (1961) and Christy (1961), whose observations have been confirmed by Meador et al. (1962) and by Jarett et al. (1964). Working with material from non-adrenal tumours removed at operation from patients with Cushing's syndrome, they have demonstrated that such tumours do in fact secrete a substance biologically and immunologically similar to ACTH, which suppresses the normal ACTH-producing mechanisms of the pituitary. It seems that the production of this ACTHlike substance is autonomous because it is not suppressed by large doses of dexamethasone.

Relation of adrenal size to adrenocortical activity. Friedman et al. (1966) discuss the relation between the endocrine activity and the size of the adrenals. They point out that there is no constant relation between size and functional activity, and quote Nichols and Gourley (1963) who postulate the existence of two types of corticotrophin, one that maintains the weight of the adrenals and the other that releases the steroids. The absence of enlargement of the adrenals in our patient could be explained in terms of this hypothesis, or by postulating that the gland would only show appreciable hypertrophy after a period of stimulation longer than that which elapsed between the onset of the disease and the removal of the tumour.

A further possibility, which cannot be ruled out on the evidence of this case, is that the islet-cell tumour might have been secreting cortisol which would have suppressed the natural adrenocortical activity of the patient's adrenal glands.

Insulin production by islet-cell tumours associated with Cushing's syndrome. It was unfortunate that we did not study our patient's sugar matabolism and insulin production before the operation. It is, however, interesting to note that in only 2 of the 9 cases referred to above was hypoglycaemia found (Balls et al., 1959; Marks et al., 1965). In the cases of Farrant and Insley, and of Jarett et al., no mention was made of the level of blood sugar. The remaining 6 cases all had hyperglycaemia.

\section{Summary}

A case is presented of Cushing's syndrome in a boy aged 2 years, associated with an islet-cell tumour of the pancreas, with symptom-free survival one year after removal of the tumour. 
REFERENCES

Allott, E. N., and Skelton, M. O. (1960). Increased adrenocortical activity associated with malignant disease. Lancet, 2, 278.

Armando, V. E. (1957). Sindrome de Cushing asociado con cancer del pancreas endocrino (caso clinico). Rev. méd. Valparaiso, $10,84$.

Bagshawe, K. D. (1960). Hypokalaemia, carcinoma and Cushing's syndrome. Lancet, $2,284$.

Balls, K. F., Nicholson, J. T. L., Goodman, H. L., and Touchstone, J. C. (1959). Functioning islet-cell carcinoma of the pancreas with Cushing's syndrome. f. clin. Endocr., 19, 1134.

Bourgeois, P., Rogé, J., Clément, D., Martin, E., and Descamps, J. (1959). Syndrome d'hypocorticisme et cancer pancréatique de type langerhansien. Bull. Soc. med. Hôp. Paris, 75, 665.

Brown, W. H. (1928). A case of pluriglandular syndrome: "diabetes of bearded women". Lancet, 2, 1022.

Castillo, E. B., del Trucco, E., and Manzuoli, J. (1950). Maladie de Cushing et cancer du pancréas. Presse méd., 58, 783.

Christy, N. P. (1961). Adrenocorticotrophic activity in the plasma of patients with Cushing's syndrome associated with pulmonary neoplasms. Lancet, 1, 85.

Cushing, H. (1932). The basophil adenomas of the pituitary body and their clinical manifestations (pituitary basophilism). Bull. Fohns Hopk. Hosp., 50, 137.

Farrant, P. C., and Insley, J. (1960). Increased adrenocortical activity and malignant disease. Lancet, 2, 434.

Frantz, V. K. (1959). Tumors of the Pancreas. (Atlas of Tumor Pathology, fasc. 27). Armed Forces Institute of Pathology, Washington.
Friedman, M., Marshall-Jones, P., and Ross, E. J. (1966). Cushing's syndrome: adrenocortical hyperactivity secondary to neoplasms arising outside the pituitary-adrenal system. Quart. F. Med., 35, 193.

Holub, D. A., and Katz, F. H. (1961). A possible etiologic link between Cushing's syndrome and visceral malignancy. (Abstr.). Clin. Res. Proc., 9, 194.

Jarett, L., Lacey, P. E., and Kipnis, D. M. (1964). Characterization by immunoflourescence of an ACTH-like substance in nonpituitary tumours from patients with hyperadrenocorticism. F. clin. Endocr., 24, 543.

Marks, V., Samols, E., and Bolton, R. (1965). Hyperinsulinism and Cushing's syndrome. Brit. med. F., 1, 1419.

Meador, C. K., Liddle, G. W., Island, D. P., Nicholson, W. E., Lucas, C. P., Nuckton, J. G., and Luetscher, J. A. (1962). Cause of Cushing's syndrome in patients with tumors arising from 'nonendocrine' tissue. F. clin. Endocr., 22, 693.

Nichols, J., and Gourley, W. (1963). Adrenal weight-maintaining corticoptropin in carcinoma of lung. f. Amer. med. Ass., 185, 696.

O'Riordan, J. L. H., Blandshard, G. P., Moxham, A., and Nabarro, J. D. N. (1966). Corticotrophin-secreting carcinomas. Quart. F. Med., 35, 137.

Rosenberg, A. A. (1956). Fulminating adrenocortical hyperfunction associated with islet-cell carcinoma of the pancreas: case report. F. clin. Endocr., 16, 1364.

Ross, E. J., Marshall-Jones, P., and Friedman, M. (1966). Cushing's syndrome: diagnostic criteria. Quart. F. Med., 35, 149. 